Dr SLOBODAN SELINIĆ, naučni saradnik

Institut za noviju istoriju Srbije

UDK 327(497.1)"1944/1946"

Beograd, Trg Nikole Pašića 11

341.7(497.1)"1944/1946"

\title{
PROMENE U DIPLOMATSKIM PREDSTAVNIŠTVIMA JUGOSLAVIJE 1944-1946*
}

\begin{abstract}
APSTRAKT: $U$ članku se razmatraju promene u jugoslovenskoj diplomatiji i diplomatskim predstavništvima na kraju Drugog svetskog rata, koje su bile posledica pobede partizanske strane u građanskom ratu $u$ Jugoslaviji.
\end{abstract}

Ključne reči: Jugoslavija, diplomatija, diplomatska predstavništva

Uz vojnu pobedu i sprovođenje revolucije u zemlji u uslovima građanskog rata, veoma važno pitanje za partizanski pokret bilo je međunarodno priznanje i preuzimanje diplomatskog aparata Kraljevine Jugoslavije, to jest njegovo čišćenje od politički nepouzdanih i neprijateljski raspoloženih službenika. Promene u diplomatskoj mreži su bile moguće posebno posle sporazuma Tita i Šubašića na Visu 16. juna 1944. i u Beogradu 1. novembra 1944. ${ }^{1}$ Ovim sporazumima je NKOJ dobio mogućnost da utiče na kadrovska rešenja u jugoslovenskoj diplomatiji još dok je rat trajao. Tako je od leta 1944. partizanski pokret vršio pritisak na Šubašića da se iz diplomatskih predstavništava Jugoslavije uklone ljudi koji su smatrani za neprijatelje NOB-a, to jest pristalice generala Mihailovića, i da se na njihova mesta postave ljudi u koje je partizanska strana imala poverenje.

Promene $\mathrm{u}$ diplomatskom aparatu nije bilo lako sprovesti. U borbi za uspostavljanje uticaja u diplomatskoj mreži Kraljevine Jugoslavije politički pragmatizam je krajem, ali i posle rata nalagao novim vlastima kompromise. Izbor kadrova za diplomatiju morao je da bude takav da se pred

* Rad je deo projekta Srbi i Srbija u jugoslovenskom i međunarodnom kontekstu: unutrašnji razvitak i položaj u evropskoj/svetskoj zajednici (47027), koji finansira Ministarstvo prosvete, nauke i tehnološkog razvoja Republike Srbije.

${ }^{1}$ B. Petranović, Istorija Jugoslavije 1918-1988, II, Beograd 1988, 318, 319, 379, 380; Đ. Tripković, Prilike u Jugoslaviji i Velika Britanija 1945-1948, Beograd 1990, 19;

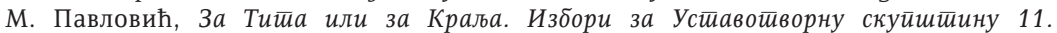
новембра 1945, Београд 2007. 
zapadnim silama otklone sumnje u isključivo komunistički karakter partizanskog pokreta. Drugo, u partijskim redovima nije bilo dovoljno ljudi koji su imali stručnost, iskustvo i koji su znali strane jezike, što su bile osobine neophodne za rad u diplomatiji. Takvo stanje nije bilo lako promeniti ni posle rata. U razgovoru sa delegacijom Slovena iz Kanade i SAD, 19. decembra 1946, Josip Broz Tito je priznao da je novim vlastima bilo teško da „popune razne konzulate i poslanstva“, jer „nemamo dovoljno iskusnih ljudi“. Obećao je da će po tom pitanju nova vlast „nešto učiniti, jer u protivnom, ta 'crna banda' može da nam učini dosta štete“. ${ }^{2}$ Slavoljub Đera Petrović u svojim memoarima navodi da je Broz 1946. godine tražio od srpske vlade i partije kadrove za diplomatiju, ali da je dobio odgovor: „Mi nemamo takve kadrove, mi smo, druže Tito, seljačka partija“. ${ }^{3}$

Komunisti koji su posle rata slati u diplomatiju mahom su bili bez diplomatskog iskustva, a veliki broj njih i bez znanja jezika. Zato su se diplomatskom zanatu učili u hodu, a mnogi ga nikada nisu ni izučili. Zato je Partija za diplomatiju primala i ljude koji ne samo da nisu bili njeni članovi, već nisu pripadali ni partizanskom pokretu. Uslov je bio da nisu sarađivali sa okupatorom ili da nisu bili na neprijateljskoj strani u ratu. Štaviše, nova vlast je iz obzira prema zapadnim silama odlučila da na čelu političkih predstavništava u nekim zapadnim državama ne budu komunisti. ${ }^{4}$ Tako su u velikom broju zemalja, pre svega zapadnih, na mestu ambasadora, poslanika i konzula godinama posle rata bili nekomunisti (Sava Kosanović u SAD, Marko Ristić u Francuskoj, Milan Ristić u Švajcarskoj i Egiptu, Božin Simić u Turskoj, Izidor Cankar u Grčkoj, Vladimir Ribarž u Norveškoj i Miloš Moskovljević u Norveškoj i Egiptu, konzuli Vladimir Vukmirović i Miodrag Marković u SAD). Doduše, KPJ se trudila da na položajima ispod šefa predstavništva u ovim diplomatskim predstavništvima budu njoj odani kadrovi: Vrleta Krulj (kasnije Šerif Šehović) u Atini, Franc Kos u Londonu, Nijaz Dizdarević u Turskoj, Sergije Makiedo, Slavko Zore i Branko Vukelić u Americi itd.

Partizanska strana je neka jugoslovenska predstavništva preuzela još tokom rata i popunjavala ih svojim ljudima, posebno posle sporazuma Tita i Šubašića. Tokom novembra 1944. Josip Smodlaka, koji je bio poverenik za spoljne poslove NKOJ-a, preuzeo je mesto jugoslovenskog delegata kod savezničkog Savetodavnog veća za Italiju umesto dotadašnjeg delegata Mihe Kreka, što je bio deo dogovora NKOJ-a i Šubašića. ${ }^{5}$ Preuzimajući

\footnotetext{
${ }^{2}$ AJ, fond 836, KMJ, I-2-a/70, Prijem delegacije Slovena...

${ }^{3}$ Slavoljub Đera Petrović, Sećanja i zapisi jednog borca i diplomate, Beograd 2007, 135.

${ }^{4}$ AJ, fond 507/XIII, SKJ, Komisija za razvoj SKJ i kadrovsku politiku, k. 47/1-32, dokument 26, Izveštaji o radu..., Prilog 3, 20. maj 1949.

${ }^{5}$ AJ, fond 372, Poslanstvo Kraljevine Jugoslavije pri Svetoj Stolici u Vatikanu, f. 18, 1944; AJ, fond 836, KMJ, I-3-b/311, Prepiska poverenika za vanjske poslove NKOJ-a
} 
delegaciju u Rimu, Josip Smodlaka se postarao i da u njoj budu ljudi odani partizanskom pokretu. Sa sobom je poveo sina Slovena. Osim njega, u radu su mu pomagali službenici, koje mu je na raspolaganje stavio privremeni štab baze NOVJ u Bariju. Posle stupanja na novu dužnost, Smodlaka je saznao da je u Napulju postojao jugoslovenski konzulat (konzularni servis), pa je po njegovom nalogu rukovodilac konzulata Jovan Ristić, koji je bio savetnik Poslanstva u Vatikanu, predao dužnost poručniku Gvidu Branici, sekretaru odeljenja za vezu NOVJ u Napulju. ${ }^{6}$

Veliki uspeh za partizanski pokret predstavljao je i prelazak na njegovu stranu ambasadora u Moskvi Stanoja Simića, koji je 1944. podneo ostavku, zajedno sa vojnim izaslanikom u SSSR-u potpukovnikom Miodragom Lozićem. Posebno tokom 1943. njih dvojica su sve više izražavali nezadovoljstvo politikom svoje vlade, stavljajući se na sovjetsku i partizansku stranu, dok u martu 1944. i konačno nisu otkazali poslušnost i stavili se na raspolaganje Josipu Brozu. ${ }^{7} \mathrm{Na}$ zahtev Tita od 12. marta, Simić i Lozić su ostali na svojim dužnostima. ${ }^{8}$

Prešavši na partizansku stranu, Simić je izdejstvovao da iz ambasade budu uklonjeni službenici koje je smatrao pristalicama generala Mihailovića i vlade Božidara Purića - savetnik Radomir Marinković i drugi sekretar Božidar Đorđević. ${ }^{9}$ Simić je istovremeno uspeo i da uz pomoć partizan-

dr Josipa Smodlake i Maršala Jugoslavije Josipa Broza Tita...; AJ, fond 334, Ministarstvo inostranih poslova Kraljevine Jugoslavije - Personalni odsek, f. 192, j. 515, Josip Smodlaka; Zapisnici NKOJ-a i Privremene vlade DFJ 1943-1945, priredili Branko Petranović, Ljiljana Marković, Beograd 1991, 31, 157; A. Milatović, Pet diplomatskih misija, I, Zagreb 1985, 19 , 20; 210; Zapisnici sa sednica Ministarskog saveta Kraljevine Jugoslavije 1941-1945, priredili Komnen Pijevac i Dušan Jončić, Beograd 2004, 450, 459.

${ }^{6}$ AJ, fond 836, KMJ, I-3-b/311, Prepiska poverenika za vanjske poslove NKOJ-a dr Josipa Smodlake i Maršala Jugoslavije Josipa Broza Tita...; J. Smodlaka, Partizanski dnevnik, Beograd 1972, 211.

${ }^{7}$ AJ, fond 836, KMJ, I-3-b/560, Pisma Stanoja Sv. Simića...; AJ, fond 378, Poslanstvo Kraljevine Jugoslavije u Kujbiševu, f. 2, 1942, Pov. akta br. 1-409; Isto, 1943, Pov. akta br. 1-334; Ояноси Јуі̄ославије и Русије (СССР) 1941-1945: gокуменйи и майеријали, приређивачи Бранко Петрановић..., Београд 1996; Коста Ст. Павловић, Райни gневник 1941-1945, Београд 2011, 273; В. Дедијер, Дневник, Београд 1951, 763; Jugoslovenske vlade u izbjeglištvu 1941-1943. Dokumenti, priredio Bogdan Krizman, Beograd-Zagreb, 1981, 3956; Jugoslovenske vlade u izbeglištvu 1943-1945. Dokumenti, priredio Branko Petranović, Beograd, Zagreb, 1981, 69, 70; Nikola B. Popović, Jugoslovensko-sovjetski odnosi u Drugom svetskom ratu, Beograd 1988, 130; А. Животић, Сйаноје Симић. Прилої биоїрафији, Југословенска дипломатија 1945-1961, зборник радова, Београд 2012.

${ }^{8}$ AJ, fond 836, KMJ, I-3-b/560, Pisma Stanoja Sv. Simića...; Dokumenti o spoljnoj politici Socijalističke Federativne Republike Jugoslavije 1941-1945, II, Beograd 1989, 56; A. Животић, Сйаноје Симић. Прилої биоірафији...

${ }_{9}^{9}$ AJ, fond 334, Ministarstvo inostranih poslova Kraljevine Jugoslavije - Personalni odsek, f. 152, j. 475, Božidar Đorđević; Isto, f. 168, j. 491, Radomir Marinković; AJ, fond 378, Poslanstvo Kraljevine Jugoslavije u Kujbiševu, f. 2, 1942, Pov. akta br. 1-409, Pov. br. 243; 
ske strane ukazom 29. septembra 1944. izdejstvuje da za sekretara Ambasade bude postavljen čovek od njegovog velikog poverenja - Radivoje Nikolajević, tada vicekonzul u Konzulatu u Jerusalimu gde je premešten po kazni 1943, sa položaja sekretara Poslanstva u Ankari. ${ }^{10}$

Pošto je prešao na partizansku stranu, Stanoje Simić je imao veliki uticaj i u određivanju jugoslovenskog predstavnika u Rumuniji, u jesen 1944. Tačnije, uspeo je da spreči predratnog savetnika ambasade Dragutina Kulmera, koji 1941. nije napustio Rumuniju zajedno sa ostalim jugoslovenskim službenicima, da se ponovo „aktivira“ i postane jugoslovenski predstavnik u Rumuniji. Simić je 26. septembra 1944. predložio Titu da on, to jest NKOJ, pošalje u Rumuniju „nekog vojnog pretstavnika“, koji bi zastupao jugoslovenske interese i održavao vezu sa sovjetskom komandom. Broz je reagovao veoma brzo i već 1. oktobra 1944. član AVNOJ-a Nikola Petrović je dobio punomoćje da $\mathrm{u}$ ime NKOJ-a zastupa interese Jugoslavije $\mathrm{u}$ Rumuniji. Njegov zadatak je bio da „preduzme organizaciju prikupljanja jugoslovenskih državljana u Narodnooslobodilačku vojsku, da preuzme imovinu i inventar bivšeg poslanstva Nezavisne države Hrvatske i Jugoslavije u Rumuniji i da reguliše sa sovjetskim pretstavnicima sva ostala pitanja koja se tiču Jugoslavije ". ${ }^{11}$ Kako je Rumunija bila poražena zemlja, Jugoslavija u njoj nije odmah obnovila rad diplomatskog predstavništva već je ustanovila političko predstavništvo, na čijem je čelu tokom 1945. bio Nikola Grulović. $^{12}$

Uticaj „nove“ Jugoslavije uspostavljen je tokom rata i u Albaniji i bio je višeslojan: politički, vojni i partijski. Od avgusta 1944. kod Vrhovnog štaba NOV Albanije nalazila se Vojna misija na čelu sa pukovnikom Velimirom Stojnićem, koji je postao i prvi jugoslovenski poslanik u Albaniji, ${ }^{13}$ dok ga u novembru 1945. nije nasledio Josip Đerđa. ${ }^{14}$

Isto, 1943, Pov. akta br. 1-334, Pov. br. 159, 231, 305; AJ, fond 836, KMJ, I-3-b/582, Depeše Stanoja Simića...; Isto, I-3-b/689, Depeše /Moše/ Pijade...; Isto, II-9-a/19, Zapisnik sa zajedničke sjednice...; DAMSP, PA, 1945, Engleska, fasc. 8, dosije 11; Jugoslovenske vlade u izbeglištvu 1943-1945..., 336, 339.

${ }^{10} \mathrm{AJ}$, fond 334, Ministarstvo inostranih poslova Kraljevine Jugoslavije - Personalni odsek, f. 152, j. 475, Božidar Đorđević; Isto, f. 178, j. 501, Radivoje Nikolajević; AJ, fond 370, Poslanstvo Kraljevine Jugoslavije u Turskoj, f. 51, j. 133, 1943; AJ, fond 507/IX, SKJ, Komisija za međunarodne odnose i veze, SSSR, IX, 119/V-1-62, dokument 2; AJ, fond 836, KMJ, I-3-b/582, Depeše Stanoja Simića...

${ }^{11}$ AJ, fond 836, KMJ, I-3-b/529, Depeša...; Isto, I-3-b/985, Depeše...

${ }^{12}$ DAMSP, PA, 1945, Rumunija, fasc. 27, dosije 18, sign. 0175.

${ }^{13}$ Zapisnici NKOJ-a..., 205; Bojan B. Dimitrijević, JNA od Staljina do NATO pakta: armija u spoljnoj politici Titove Jugoslavije, Beograd 2005, 62; А. Животић, Јуїославија, Албанија и велике силе 1945-1961, Београд 2011.

${ }^{14}$ DAMSP, PA, 1945, Albanija, fasc. 1, dosije 16, sign. 6136. 
Jedan od prioriteta NKOJ-a posle sporazuma Tita i Šubašića bilo je popunjavanje diplomatske mreže odanim ljudima i uklanjanje onih koje je NKOJ smatrao za neprijatelje. To je bio deo dogovora NKOJ-a i Šubašića posle formiranja Šubašićeve vlade. Taj proces je zahtevao vreme, ali kako se NKOJ-u žurilo sa partizanske strane su često stizale primedbe da Šubašić ne ispunjava dogovor o čišćenju diplomatskog aparata od protivnika NKOJa. Šubašićeva vlada, međutim, nije bila toliko inertna po ovom pitanju. Već 9. juna donet je ukaz o penzionisanju ambasadora u Vašingtonu Konstantina Fotića, diplomati o kojem je partizanska strana verovatno imala najlošije mišljenje. Na sednici vlade 17. jula 1944. razmatrano je pitanje „reorganizacije i čišćenja u Ministarstvu inostranih poslova i diplomatskoj službi“. Tada je odlučeno da bude penzionisan poslanik u Bernu Momčilo Jurišić, a raspravljalo se i o novim ambasadorima u Moskvi i Vašingtonu. ${ }^{15}$ Ipak, partizanskoj strani to nije bilo dovoljno. Sećajući se susreta ministara Šubašićeve vlade i članova NKOJ-a na Visu, avgusta 1944, Velebit je primetio da su u to vreme "diplomatski predstavnici skoro u svim zemljama, sa časnim izuzetkom Stanoja Simića u Sovjetskom Savezu, podržavali politiku kraljevskih vlada i postali rasadnici Mihailovićevog kulta i glasnogovornici četničke propagande". ${ }^{16}$ Zato su prilikom sastanka na Visu i posle njega vršeni novi pritisci partizanske strane na Šubašića. O tome je Šubašić obavestio Vladu na sednici 25. septembra. Preneo je ministrima da „Maršal Tito ponovo urgira popunjenje diplomatskih mesta u Vašingtonu, Parizu, Kairu, Otavi“, a potom je zaključeno da poslanik u Kairu bude Milan Martinović. Novi korak je učinjen na sednici vlade 12 . oktobra, kada je penzionisan ili stavljen na raspolaganje veliki broj diplomata, a među njima i još dvojica velikih protivnika komunista - Aleksandar Avakumović (Švedska) i Bogoljub Jevtić (Engleska). ${ }^{17}$

Mada je NKOJ uspeo da u nekim diplomatskim predstavništvima Kraljevine Jugoslavije ostvari uticaj još tokom 1944, poput Ambasade u SSSR-u ili delegacije u Italiji, u većini predstavništava do osetnijih promena došlo je tek posle rata, to jest posle formiranja Privremene Vlade DFJ na čelu sa Titom, marta 1945. To znači da su se u mnogim predstavništvima i posle rata zadržali stari kadrovi i da su oni postepeno zamenjivani od 1945, čime su i diplomatska predstavništva Kraljevine Jugoslavije i formalno prerastala u diplomatska predstavništva DFJ ili FNRJ. Stvaranje Privremene Vlade DFJ na čelu sa Josipom Brozom marta 1945. olakšalo je popunjavanje diplomatskih predstavništava ljudima u koje je nova vlast imala poverenje.

${ }^{15}$ Zapisnici sa sednica Ministarskog saveta Kraljevine Jugoslavije..., 443, 444.

${ }^{16}$ V. Velebit, Sećanja, Zagreb 1983, 294.

${ }^{17}$ Zapisnici sa sednica Ministarskog saveta Kraljevine Jugoslavije 1941-1945, priredili Komnen Pijevac i Dušan Jončić, Beograd 2004, 455, 456, 459, 460. 
Tako su uglavnom tokom 1945. diplomate odane novim vlastima krenule i $\mathrm{u}$ ona diplomatska predstavništva u kojima do tada nova vlast nije imala svoje ljude na njihovom čelu. Na sednici Vlade 30. marta 1945. konačno su određeni ambasadori u više značajnih svetskih prestonica, među kojima su bile i neke u kojima ambasadora dugo nije bilo. Tada su određeni za ambasadore u SAD Stanoje Simić, Moskvi Vladimir Popović (umesto Stanoja Simića), Londonu Ljubo Leontić i Parizu Marko Ristić. Tokom 1945. odlučeno je i da Milan Ružić bude konzul u Carigradu, a Božin Simić ambasador u Ankari. ${ }^{18}$

Među predstavništvima u kojima su stari kadrovi ostali do posle rata bili su Ambasada u Kanadi, Konzulat u Carigradu, Ambasada u Londonu, Poslanstvo u Portugalu, Ambasada u Turskoj, predstavništva u SAD itd. Trn u oku partizanima ostalo je nekoliko jugoslovenskih diplomata: ambasador u SAD Konstantin Fotić, ambasador u Londonu Bogoljub Jevtić, ambasador u Švedskoj Aleksandar Avakumović, poslanik u Bernu Momčilo Jurišić i delegat kod De Golovog Komiteta Jovan Đonović. Zato su leto i jesen 1944. protekli u stalnim pritiscima na Šubašićevu vladu da se oni uklone sa položaja i zamene ličnostima prihvatljivim pobedničkoj strani u jugoslovenskom građanskom ratu.

Krajem 1944. u Engleskoj je poslanik bio Bogoljub Jevtić, predratni predsednik vlade i ministar koji se na tom položaju nalazio od septembra 1943, ali je nezadovoljstvo partizanske strane stanjem u ovom predstavništvu Jugoslavije bilo takvo da ga je Vladimir Velebit označio za "leglo neprijateljskih mahinacija“. ${ }^{19}$ Šubašić nije pokazivao želju da Jevtića zameni, smatrajući da "nema prepreke" da on ostane na tom položaju, jer se u Londonu nalazila i vlada, pa on nije imao mogućnosti da šteti. ${ }^{20}$ Ipak, morao je da popusti, pa je njegova vlada 12. oktobra 1944. odlučila da Jevtić bude penzionisan. ${ }^{21}$ Otpravnik poslova postao je Vladimir Ribarž, karijerni diplomata Kraljevine Jugoslavije, koji je bio prihvatljiv za NOP. Za njega je Velebit pisao da je bio „vrlo sposoban diplomatski službenik. Čovek neprikosnovenog integriteta i diskretno naklonjen NOP-u“. ${ }^{22}$ Imenovanje

${ }^{18}$ AJ, fond 836, KMJ, II-5-b/33, Zapisnici sa sednica...

${ }^{19} \mathrm{AJ}$, fond 836, KMJ, I-3-b/990, Izveštaj...

${ }^{20}$ AJ, fond 836, KMJ, II-9-a/19, Zapisnik sa zajedničke sjednice...

${ }^{21}$ Zapisnici sa sednica Ministarskog saveta Kraljevine Jugoslavije 1941-1945..., str. 460; Sava N. Kosanović, Jugoslavija bila je osuđena na smrt. Smisao Moskovskog sporazuma, pripremio za štampu i uvodne napomene napisao Bogdan Krizman, Ljubljana 1984, 238.

${ }^{22}$ Vladimir Ribarž je posle rata bio jugoslovenski ambasador u Norveškoj. Na to mesto je imenovan februara 1946, ali je već 14. novembra 1946. preminuo u Oslu. AJ, fond 334, Ministarstvo inostranih poslova Kraljevine Jugoslavije - Personalni odsek, f. 188, j. 511, Vladimir Ribarž; V. Velebit, Sećanja, Zagreb 1983, 359. 
novog ambasadora sačekalo je stvaranje privremene Vlade DFJ, pa je na sednici održanoj 30. marta 1945. usvojen predlog da ambasador bude Ljubo Leontić. ${ }^{23}$

U drugoj polovini 1944. mnogo bolja situacija iz ugla NKOJ-a nije bila ni u Stokholmu, gde je otpravnik poslova (poslanik) bio Aleksandar G. Avakumović. Mada su Avakumović i jugoslovensko Poslanstvo nastojali da pomognu jugoslovenskim izbeglicama i interniranim jugoslovenskim diplomatama, radom jugoslovenskog Poslanstva i poslanika nisu bili zadovoljni Jugosloveni pristalice NOP-a. Za Avakumovića je Velebit javio da je „Dražin čovek" i da se „ponaša odvratno prema našim ljudima, koji beže iz Norveške". ${ }^{24}$ Krajem godine i on je uklonjen iz Stokholma. Odluka o njegovom penzionisanju doneta je na sednici Šubašićeve vlade 12. oktobra 1944, a na istoj sednici je odlučeno da ga zameni Rajko Đermanović. ${ }^{25}$ Đermanović je bio jedan od predratnih građanskih političara, politički podoban novim vlastima. U Stokholm je doputovao 2. juna 1945. i odmah „saobrazio Poslanstvo novom poretku u pogledu Kraljevih slika, zastave, grba i imena države". ${ }^{26}$

Momčilo Jurišić Šturm, poslanik u Bernu još od 1940. godine, takođe je za partizansku stranu bio „Dražin agent" ${ }^{27}$ Nezadovoljstvo radom Jurišića i jugoslovenskog poslanstva u Bernu iskazao je 1944. i Komitet narodnog oslobođenja Jugoslavije u inostranstvu, koji je u pismu NKOJ-u upozorio na maltretiranje pristalica NOV-a u Švajcarskoj po nalogu Poslanstva ${ }^{28}$ Postavljanje Šubašićeve vlade i politika sporazuma sa Titom značili su i kraj Jurišićevog rada u Švajcarskoj. Šubašićeva vlada je već 27. jula 1944. odlučila da on bude penzionisan, o čemu je donet ukaz 28. jula $1944 .{ }^{29} \mathrm{Na}$ njegovo mesto je došao Milan Ristić, koji je tokom Drugog

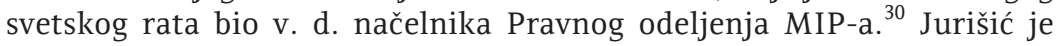

${ }^{23}$ Zapisnici NKOJ-a i Privremene vlade DFJ 1943-1945..., 84.

${ }^{24}$ AJ, fond 836, KMJ, I-3-b/982, Izveštaj general-majora Vladimira Velebita...; AJ, fond 836, KMJ, I-3-b/986, Depeše...; AJ, fond 382, Poslanstvo Kraljevine Jugoslavije u Švedskoj - Stokholm, f. 15, j. 52; f. 15, j. 53.

${ }^{25}$ Zapisnici sa sednica Ministarskog saveta Kraljevine Jugoslavije 1941-1945..., 460; Коста Ст. Павловић, Райни невник 1941-1945..., 465.

${ }^{26}$ DAMSP, PA, 1945, Švedska, fasc. 32, dosije 11, sign. pov. br. 1246, 1310, 2192.

${ }^{27}$ AJ, fond 836, KMJ, I-3-b/982, Izveštaj general-majora Vladimira Velebita...; AJ, fond 836, KMJ, I-3-b/986, Depeše...

${ }^{28}$ AJ, fond 836, KMJ, II-9-b/41, Pismo Komiteta...

${ }^{29}$ AJ, fond 334, Ministarstvo inostranih poslova Kraljevine Jugoslavije - Personalni odsek, f. 160, j. 483, Momčilo Jurišić Šturm; Коста Ст. Павловић, Райни gневник 19411945..., 431, 449; Zapisnici sa sednica Ministarskog saveta Kraljevine Jugoslavije 1941-1945..., 444.

${ }^{30}$ AJ, fond 334, Ministarstvo inostranih poslova Kraljevine Jugoslavije - Personalni odsek, f. 188, j. 511, Milan Ristić; AJ, fond 378, Poslanstvo Kraljevine Jugoslavije u Kujbiševu, f. 2, 1943, Pov. akta br. 1-334, Pov. br. 124. 
predao dužnost Ristiću decembra $1944 .{ }^{31}$ Posle oslobođenja Jugoslavije, jugoslovensko Poslanstvo u Bernu uspelo je i da izdejstvuje od švajcarske vlade zatvaranje Stalne trgovinske delegacije NDH u Cirihu. Poslanstvo je odredilo komisiju na čijem čelu je bio generalni konzul u Cirihu Đorđe Đuričić i ona je preuzela ovo ustaško predstavništvo 19. maja $1945 .^{32}$

Važna diplomatska prestonica bio je i Pariz. Iz ugla NKOJ-a, 1944. i 1945. bilo je neophodno pronaći i predstavnika u Francuskoj umesto Jovana Đonovića. Kao delegat kraljevske vlade kod Šarla de Gola, Đonović se zalagao za generala Mihailovića. ${ }^{33}$ Sa njegovim penzionisanjem se složio i Šubašić, pa ga je Šubašićeva vlada penzionisala na sednici od 24. avgusta 1944, odmah posle sastanka sa NKOJ-em na Visu. Njegovo penzionisanje je bila jedna od prvih posledica dogovora Šubašića i partizanske strane da se diplomatski aparat očisti od pristalica generala Mihailovića. ${ }^{34}$ Vladimir Velebit je razmišljao o Božinu Simiću kao rešenju za mesto ambasadora u Parizu, ali je zaključio da Simić ipak nije „podesan“, jer „nije čvrsto na platformi n. o. pokreta". Simića kao budućeg ambasadora u Parizu pomenuo je i Stojan Gavrilović, septembra 1944, u razgovoru sa Josipom Smodlakom. Drugi kandidat je bio Boris Furlan, ali je Velebit sumnjao da je on bio „engleski čovek“. Na hitnost postavljanja NKOJ-u odanog čoveka na mesto ambasadora u Parizu, partizanski pokret je terao i strah od četničke propagande u Francuskoj. Vladimir Velebit je bio svestan nemogućnosti da se toj propagandi adekvatno parira bez pouzdanih ljudi na čelu diplomatskog predstavništva. Pitanje imenovanja ambasadora u Parizu rešeno je tek posle rata, kada je na to mesto postavljen komunistima odani Marko Ristić. $^{35}$

Borba za preuzimanje Ambasade u Vašingtonu trajala je dosta dugo. Tokom 1944. NKOJ je postigao uspeh utoliko što je penzionisan ambasador Konstantin Fotić, pristalica generala Mihailovića. Ukaz o njegovom penzionisanju donet je 9. juna 1944, posle čega je Fotić nastavio da se bori protiv svog penzionisanja, osporavajući legitimitet Šubašićevoj vladi. Konačno, 14. jula 1944. saopštio je Ivanu Frangešu, otpravniku poslova, da će napustiti

${ }^{31}$ AJ, fond 334, Ministarstvo inostranih poslova Kraljevine Jugoslavije - Personalni odsek, f. 160, j. 483, Momčilo Jurišić Šturm; Коста Ст. Павловић, Райни gневник 19411945..., 431, 449; DAMSP, PA, 1945, Švajcarska, fasc. 31, dosije 17.

${ }^{32}$ DAMSP, PA, 1945, Švajcarska, fasc. 31, dosije 7.

${ }^{33}$ B. Petranović, Srbija u Drugom svetskom ratu 1939-1945, Beograd 1992, 167.

${ }^{34}$ AJ, fond 103, Emigrantska vlada Kraljevine Jugoslavije, f. 3, j. 37; Zapisnici sa sednica Ministarskog saveta Kraljevine Jugoslavije 1941-1945..., 448.

${ }^{35}$ AJ, fond 836, KMJ, I-3-b/990, Izveštaj...; AJ, fond 836, KMJ, I-3-b/982, Izveštaj general-majora Vladimira Velebita...; AJ, fond 836, KMJ, I-3-b/986, Depeše...; J. Smodlaka, Partizanski dnevnik, Beograd 1972, 188. 
Ambasadu. ${ }^{36}$ Od tog dana je Frangeš i zvanično postao otpravnik poslova Ambasade $u$ Vašingtonu. ${ }^{37}$

Smenjivanje Fotića je bio samo prvi korak u preuzimanju Ambasade u SAD. Posle toga je trebalo odrediti novog ambasadora, ali dosta dugo nije bilo moguće pronaći pogodnu ličnost. Hitnost slanja ambasadora u SAD nalagao je i strah od aktivnosti bivšeg ambasadora Fotića, to jest procena da je Fotić bio „vrlo vešt i inteligentan diplomata i da je u krugovima u Vašingtonu važio kao najsposobniji među svim diplomatskim pretstavnicima. On je uspio da stvori vrlo jake i uticajne lične veze“ ${ }^{38} \mathrm{O}$ pitanju izbora Fotićevog naslednika nije bilo dogovora između Šubašića i partizanske strane. Šubašićeva ideja da postavi Mihaila Konstantinovića, koji je bio ministar u vladi Cvetković-Maček ali je dao ostavku zbog pristupanja Trojnom paktu, naišla je na protivljenje Save Kosanovića, kandidata NKOJ-a za tu funkciju i Velebita, koji je za Konstantinovića pisao da je „pametan, slobodni zidar i dosta opasan“. Mada je podržavao zajedničku borbu u zemlji protiv okupatora Konstantinović, za razliku od Kosanovića nije jednostrano stao na partizansku stranu i nije želeo da uđe u Šubašićevu vladu posle sporazuma Tita i Šubašića, i pored stalnih Šubašićevih insistiranja da to učini. ${ }^{39}$ Sa druge strane, izboru Kosanoviću za ambasadora u SAD protivio se Šubašić, smatrajući da je Kosanović „političar i temperamentni vođa jednog dela naše emigracije". Velebit je priznavao da Kosanović zaista nije najidealnije rešenje, jer bi se on više bavio unutrašnjim pitanjima jugoslovenske emigracije, ali i da boljeg kandidata nije bilo. ${ }^{40}$ Na zajedničkoj sednici NKOJ-a i predstavnika kraljevske vlade, održanoj u drugoj polovini avgusta 1944, Kosanović je pretio ostavkom ako Konstantinović bude izabran za ambasadora. Podržali su ga Kardelj, Žujović i Smodlaka. ${ }^{41}$ Za razliku od Kosanovića, koji

${ }^{36}$ AJ, fond 103, Emigrantska vlada Kraljevine Jugoslavije, f. 15, j. 118, 1944; AJ, fond 371, Poslanstvo Kraljevine Jugoslavije u SAD - Vašington, f. 69, j. 91, Konstantin Fotić; Jugoslovenske vlade u izbeglištvu 1943-1945.., 337, 338, 345, 346, 352, 353; Коста Ст. Павловић, Райни дневник 1941-1945..., 406, 407; Sava N. Kosanović, Jugoslavija bila je osuđena na smrt..., 64.

${ }^{37}$ AJ, fond 371, Poslanstvo Kraljevine Jugoslavije u SAD - Vašington, f. 69, j. 91, Ivan Frangeš.

${ }^{38} \mathrm{AJ}$, fond 836, KMJ, I-3-b/982, Izveštaj general-majora Vladimira Velebita...; AJ, fond 836, KMJ, I-3-b/986, Depeše...

${ }^{39}$ U julu 1944. Konstantinović je odbio da uđe u Šubašićevu vladu uveren da je ona, po Sporazumu sa Titom, „nemoćna, podređena partizanima..., dosta jadna, u nekom stavu moljenja“, da se „podređuje“ NOP-u. Mihailo Konstantinović, Politika sporazuma: dnevničke beleške 1939-1941; londonske beleške 1944-1945, Novi Sad 1998, 368, 370, 384.

${ }^{40} \mathrm{AJ}$, fond 836, KMJ, I-3-b/982, Izveštaj general-majora Vladimira Velebita...; AJ, fond 836, KMJ, I-3-b/986, Depeše...; M. Terzić, „Misija Vladimira Velebita u Londonu - leto 1944“, Vojnoistorijski glasnik, 3/1998, 101.

${ }^{41}$ AJ, fond 836, KMJ, II-9-a/19, Zapisnik sa zajedničke sjednice...; J. Smodlaka, Partizanski dnevnik, Beograd 1972, 178, 179. 
se odlučno protivio Konstantinoviću i isticao sebe kao kandidata za ambasadora, Konstantinović je bio neodlučan, a kada je saznao za prepreke njegovom imenovanju za ambasadora i za oštro protivljenje Kosanovića, reagovao je pomirljivo i uzdržano. ${ }^{42}$ Posle sastanka na Visu avgusta 1944, jedno vreme se razmišljalo i o Izidoru Cankaru kao kandidatu za ambasadora u SAD, ali se brzo odustalo. ${ }^{43}$ Dilema oko ličnosti ambasadora u SAD je razrešena tek kada je Stanoje Simić povučen iz Moskve i poslat u SAD, aprila 1945. U međuvremenu je sve vreme otpravnik poslova bio dr Ivan Frangeš. ${ }^{44}$

Veliku važnost imalo je i jugoslovensko predstavništvo u Kairu. Zato je, poput Vašingtona, i za Kairo bilo više kandidata i mnogo kolebanja i neodlučnosti. Važnost ovog predstavništva navela je Josipa Smodlaku da avgusta 1944. na zajedničkoj sednici predstavnika kraljevske vlade i NKOJa predloži za poslanika majora Matu Jakšića, člana Vojne misije NKOJ-a u Velikoj Britaniji (ured u Kairu). ${ }^{45}$ Šubašić je, međutim, imao drugačije planove. Mihailo Konstantinović navodi da mu je nekoliko dana posle ovog sastanka sa NKOJ-em, Šubašić poverio da će u Kairo za poslanika poslati Stojana Gavrilovića, tada pomoćnika ministra inostranih poslova. ${ }^{46} \mathrm{U}$ svakom slučaju, uskoro je ovo pitanje rešeno, a izbor je pao na dr Milana Martinovića, bivšeg ministra finansija i trgovine u Purićevoj vladi, a sa time se složio i Tito. Martinović je za poslanika imenovan na sednici Vlade 25. septembra, a akreditive je predao 2 . novembra $1944 .{ }^{47}$ Bilo kako bilo, pozicije NKOJ-a u Kairu nisu ojačale. Mato Jakšić je iskazivao veliko nezadovoljstvo sastavom Poslanstva u Kairu krajem 1944. Iako je prema dogovoru Jakšića sa Stojanom Gavrilovićem i Martinovićem, tokom njihovih susreta u septembru i oktobru 1944, trebalo da Jakšić među jugoslovenskim izbeglicama u El Šatu pronađe nekoliko ljudi sposobnih za diplomatsku službu, kako bi ih vlada premestila u diplomatska predstavništva na Srednjem istoku, to se nije desilo, već su u Poslanstvo u Kairu postavljeni ljudi koji se nisu mogli

${ }^{42}$ AJ, fond 103, Emigrantska vlada Kraljevine Jugoslavije, f. 15, j. 118, 1944; Mihailo Konstantinović, Politika sporazuma..., 410-413; Jugoslovenske vlade u izbeglištvu 1943$1945 \ldots, 369$.

${ }^{43}$ J. Smodlaka, Partizanski dnevnik, Beograd 1972, 183, 187.

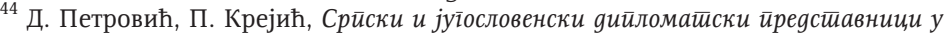
Сјеgиюеним Америчким Државама 1917-1945, Архив, часопис Архива Србије и Црне Горе, год. VIII, бр. 1-2, Београд 2007, 194.

${ }^{45}$ AJ, fond 836, KMJ, II-9-a/19, Zapisnik sa zajedničke sjednice...; J. Smodlaka, Partizanski dnevnik, Beograd 1972, 179.

${ }^{46}$ Mihailo Konstantinović, Politika sporazuma..., 410.

${ }^{47}$ AJ, fond 103, Emigrantska vlada Kraljevine Jugoslavije, f. 15, j. 118, 1944; Jugoslovenske vlade u izbeglištvu 1943-1945..., 401-403; J. Smodlaka, Partizanski dnevnik..., 188; Zapisnici sa sednica Ministarskog saveta Kraljevine Jugoslavije 1941-1945..., 455. 
smatrati pristalicama NOP-a. ${ }^{48}$ Situacija se, iz ugla novih vlasti, popravljala tokom 1945, kada su zamenile nepouzdanog predstavnika pouzdanim. Umesto građanskog političara poslanik je postao komunista. U leto 1945. Milan Martinović je smenjen sa mesta poslanika u Egiptu i primoran da napusti Poslanstvo. ${ }^{49}$ Novi poslanik Ešref Badnjević došao je u Kairo 18. decembra 1945, a akreditive je predao u januaru $1946 .^{50}$

Dugo posle rata, kao prelazno rešenje, na mestu otpravnika poslova u Kanadi se zadržao stari kadar Petar Cabrić, generalni konzul u Montrealu. On je imenovan za otpravnika poslova oktobra 1944. rešenjem Šubašićeve vlade. Dužnost je preuzeo 21. oktobra od savetnika Radoja Nikolića. ${ }^{51}$ Cabrića su delegati kanadskih Slovena kritikovali kod Broza 19. decembra 1946. da se drži „pasivno“ i da je „Šubašićev lični prijatelj“, pa bi „trebalo nešto uraditi“. Tito je odgovorio: „Treba ga skinuti. Jednostavno ćemo ga skinuti“. ${ }^{52}$ Čini se da je tako i postupljeno. Cabrić uskoro više nije bio otpravnik poslova u Otavi. Početkom 1947. otpravnik poslova je nakratko bio Miodrag Marković, a u februaru 1947. za otpravnika poslova je imenovan Pavle Lukin, koji je ostao na tom mestu godinu i po, sve do leta 1948, jer je kanadska vlada uporno odugovlačila sa davanjem agremana za jugoslovenskog poslanika Matu Jakšića. Jugoslavija je agreman za Jakšića tražila u martu 1947, on je u Otavu doputovao tek u junu 1948, a akreditive je predao 8. jula. ${ }^{53}$ Poput Kanade, ratna kadrovska rešenja su dugo posle rata potrajala i u dalekoj Australiji, gde je Šubašićeva vlada 1944. umesto počasnog konzula u Sidneju Mikuličića, Hrvata iz Sušaka, australijskog podanika, u koga nove vlasti nisu imale poverenja smatrajući ga „reakcionarom“, imenovala Ivana Kosovića, takođe jugoslovenskog iseljenika, koji je bio i čelnik Saveza jugoslovenskih iseljenika Australije, sakupljao finansijsku i materijalnu pomoć za Jugoslaviju tokom rata i bio urednik jugoslovenskog lista Napredak u Sidneju. ${ }^{54}$

Do promena $\mathrm{u}$ jugoslovenskim diplomatskim predstavništvima $\mathrm{u}$ Turskoj došlo je posle rata, to jest tokom 1945. Pobeda partizanskih snaga značila je i kraj diplomatske karijere ambasadora u Ankari Ilije Šumenkovića,

${ }^{48}$ AJ, fond 836, KMJ, I-3-b/987, Izveštaji...

${ }^{49}$ DAMSP, PA, 1945, Jugoslavija, fasc. 17, dosije 4.

${ }^{50}$ DAMSP, PA, 1946, Egipat, fasc. 21, dosije 3, sign. pov. br. 93; Isto, dosije 9, sign. pov. br. 374, v. br. 1117.

${ }^{51}$ AJ, fond 39, Poslanstvo Kraljevine Jugoslavije u Kanadi - Otava, f. 5, j. 13.

${ }^{52}$ AJ, fond 836, KMJ, I-2-a/70, Prijem delegacije Slovena...

${ }^{53}$ DAMSP, PA, 1947, Kanada, fasc. 68, dosije 8, 9 i 15; Isto, 1948, Kanada, fasc. 93 , dosije 2, 5 .

${ }^{54}$ AJ, fond 507/IX, SKJ, Komisija za međunarodne odnose i veze, Australija, IX, 5/IV-1-22, dokumenta 1 i 2; AJ, fond 836, KMJ, I-3-b/66, Pismo Glavnog odbora...; AJ, fond 341, Poslanstvo Kraljevine Jugoslavije, London, f. I, 1944/1945. 
predratnog ministra i diplomate, jer su političke ocene novih vlasti o njemu bile veoma negativne. ${ }^{55}$ Šumenković je ukazom kraljevskih namesnika stavljen na raspolaganje 20 . avgusta 1945 , ali je odbio da se vrati u zemlju i dao ostavku na dužnost. Za novog ambasadora 20. avgusta 1945. imenovan je Božin Simić. ${ }^{56}$ Simić je u Ankaru krenuo početkom oktobra, ali je 9. oktobra prilikom polaska iz Sofije za Tursku povređen „od jednog automobila, koji je naleteo na njega“, pa je njegov odlazak na novu dužnost usporen lečenjem. ${ }^{57}$ Dužnost u Ankari preuzeo je tek krajem januara, a akreditivno pismo je predao početkom februara $1946 .^{58}$ Funkciju otpravnika poslova vršio je Rafo Arneri, predratni diplomata, kome je Šumenković predao dužnost 30. avgusta $1945 .{ }^{59}$ U međuvremenu je Ljubo Leontić iz Londona, po naređenju MIP-a, naložio Ambasadi u Ankari da se iz Ambasade i drugih predstavništava uklone kraljeve slike, jer je to „jasna i logična posledica prenosa Kraljevskih prerogativa na Namesništvo". Ovom naređenju se suprotstavio vojni izaslanik, general Velimir Ranosović. ${ }^{60} \mathrm{U}$ Generalnom konzulatu u Carigradu promene su počele od oktobra 1944. Tada je stavljen na raspolaganje generalni konzul Luka Luković i naloženo mu je da preda dužnost konzulu Bogdanu Đoleviću, što je on i uradio 1. novembra. Đolević je vršio dužnost generalnog konzula, sve dok krajem maja 1945. nije dobio naređenje MIP-a DFJ da preda dužnost, arhivu i imovinu konzulata Mitru Ćetkoviću, zvaničniku konzulata i da se sa svim osobljem i njihovim familijama vrati u Beograd. Ministarstvo inostranih poslova je potom obavestilo Ambasadu u Ankari 11. jula 1945. da je za generalnog konzula u Carigradu postavljen Milan Ružić, a za vicekonzula Jovan Vukotić. ${ }^{61}$

Tokom 1945. nove diplomate stigle su i u Čehoslovačku, Poljsku i Bugarsku. Ukazom kraljevskih namesnika od 11. maja 1945. za poslanika u Čehoslovačkoj je postavljen dr Darko Černej. Ministarstvo inostranih poslova je 18. septembra 1945. za generalnog konzula u Bratislavi postavilo inž.

${ }^{55}$ AJ, fond 334, Ministarstvo inostranih poslova Kraljevine Jugoslavije - Personalni odsek, f. 206, j. 529, Ilija Šumenković.

${ }^{56}$ AJ, fond 370, Poslanstvo Kraljevine Jugoslavije u Turskoj, f. 52, j. 134.

${ }^{57}$ DAMSP, PA, 1945, Turska, Vatikan, fasc. 33, dosije 17; Isto, 1946, Turska, fasc. 84 , dosije 13, sign. pov. br. 5506.

${ }^{58}$ DAMSP, PA, 1946, Turska, fasc. 84, dosije 14, sign. pov. br. 1075, 1284.

${ }^{59}$ DAMSP, PA, 1945, Turska, Vatikan, fasc. 33, dosije 17, sign. pov. br. 3874.

${ }^{60}$ Ranosović je u avgustu 1945. opozvan u zemlju naređenjem Ministarstva narodne odbrane, ali je dužnosti razrešen tek u novembru „usled toga što je namerno odugovlačio odsustvovanjem iz Ankare“. AJ, fond 411, Generalni konzulat Kraljevine Jugoslavije u Carigradu, f. 9, j. 22, 1945; AJ, fond 370, Poslanstvo Kraljevine Jugoslavije u Turskoj, f. 51, j. 133, 1945.

${ }^{61}$ AJ, fond 370, Poslanstvo Kraljevine Jugoslavije u Turskoj, f. 52, j. 134; AJ, fond 411, Generalni konzulat Kraljevine Jugoslavije u Carigradu, f. 24, j. 50, 1945; Isto, f. 9, j. 22 , 1945. 
Ivana Mahulju. ${ }^{62}$ Prvi posleratni ambasadori u Sofiji i Varšavi bili su stari komunisti: Nikola Kovačević u Sofiji i Božo Ljumović, kasniji ibeovac, u Varšavi. Ljumović je u poljsku prestonicu doputovao 5. juna, a akreditive je predao 12. juna $1945 .^{63}$

Jugoslavija je tokom 1945. nameravala da njen poslanik u Švedskoj Rajko Đermanović bude istovremeno akreditovan i u Danskoj i u Norveškoj. Danska je na to pristala, ali Norveška nije, predlažući da u Oslu bude zaseban jugoslovenski poslanik. Zato je krajem godine Jugoslavija odlučila da u Oslu otvori posebno jugoslovensko Poslanstvo. ${ }^{64} \mathrm{U}$ februaru 1946. za poslanika u Norveškoj imenovan je Vladimir Ribarž. On je 6. aprila predao kralju Hakonu akreditivna pisma. ${ }^{65}$ Poslanik u Švedskoj Đermanović bio je istovremeno akreditovan i u Danskoj, gde je akreditive danskom kralju predao 15. juna $1946 .^{66}$

Nove jugoslovenske vlasti su 1945. odlučile da likvidiraju jugoslovensko Poslanstvo u Madridu. Ministar inostranih poslova Šubašić je 27. marta 1945. tražio od otpravnika poslova Ambasade u Londonu Vladimira Ribarža da naredi otpravniku poslova u Madridu Ljubiši Višackom, koji je u leto 1940. postao sekretar Poslanstva u Madridu, i svim drugim licima u diplomatskoj i konzularnoj službi u Madridu da napuste Španiju i otputuju u Jugoslaviju. Višacki je, međutim, odbio da se povinuje naređenju. Zato je Ribarž predložio da se Višacki odmah otpusti, što je i urađeno. ${ }^{67}$

Osetljivost diplomatije i obzire KPJ prema zapadnim silama na kraju rata pokazivala je i činjenica da u Privremenoj vladi DFJ formiranoj 7. marta 1945. resor spoljnih poslova nije bio u rukama komunista. Formalno ga je vodio ministar Ivan Šubašić, mada je stvarno spoljna politika bila u rukama Josipa Broza Tita i Politbiroa CK KPJ. Šubašić je na tom mestu ostao do ostavke, oktobra $1945 .{ }^{68}$ Osim spoljne politike, komunistička vlast se starala da stavi pod kontrolu i Ministarstvo inostranih poslova i kadrovsku politiku u ministarstvu, a o tome su se tokom februara 1945, i pre dolaska Šubašića u zemlju dogovarali Kardelj, Josip Smodlaka i Ljubo Leontić. Trebalo je pre nego što Šubašić dođe u zemlju na osetljiva mesta u njegovom ministarstvu postaviti partijski pouzdane kadrove, ali se ipak shvatilo

${ }^{62}$ S. Selinić, Jugoslovensko-čehoslovački odnosi 1945-1955, Beograd 2010, 66; C. Селинић, Јуі̄ословенски йреgстиавниии у Чехословачкој 1945-1948/9, Југословенска дипломатија 1945-1961, зборник радова, Београд 2012.

${ }^{63}$ DAMSP, PA, 1945, Poljska, fasc. 25, dosije 12.

${ }^{64}$ DAMSP, PA, 1945, Švedska, fasc. 32, dosije 11, 21.

${ }^{65}$ DAMSP, PA, 1946, Norveška, fasc. 71, dosije 9, sign. pov. br. 5360.

${ }^{66}$ DAMSP, PA, 1946, Danska, fasc. 20, dosije 11, sign. pov. br. 8176.

${ }^{67}$ DAMSP, PA, 1945, SSSR, Španija, fasc. 30, dosije 19.

${ }^{68}$ AJ, fond 836, KMJ, II-5-b/31, Ostavka Ivana Šubašića na dužnost ministra inostranih poslova, 6. oktobar 1945. 
da se ne mogu dovoditi ljudi bez ikakvog diplomatskog iskustva, samo zato što su komunisti. ${ }^{69}$ Činovnici koje je Šubašić postavio u ministarstvo bili su pod budnim okom OZN-e, praćen je njihov odnos prema novim vlastima, ispitivana politička i profesionalna prošlost, praćeni su njihovi eventualni kontakti sa diplomatskim predstavnicima zapadnih država, a oni među njima koji su bili u kabinetu ministra inostranih poslova, kada je Šubašić bio ministar, premešteni su iz kabineta posle Šubašićeve ostavke. ${ }^{70}$ Od Šubašićeve ostavke do 1. februara 1946. dužnost ministra inostranih poslova vršio je Josip Broz Tito, a februara 1946. ministar je postao Stanoje Simić, koji se zadržao na tom mestu sve do sukoba sa Informbiroom.

Slobodan Selinić

THE CHANGES IN THE YUGOSLAV DIPLOMATIC REPRESENTATIVES 1944-1946

\section{Summary}

While still in the struggle for definitive power in the Yugoslavia 1944-1946, the Communist Party worked hardly to expel all its potential enemies from the Yugoslav diplomacy. The Party aim was to create the stabile and obedient diplomats, loyal to its cause and ideology. But, the problem was the lack of the skilled diplomats inside the Party ranks. After the political agreement and creation of the Tito-Šubašić government in summer 1944, the process of introducing communist diplomats started. Some of the diplomats previously loyal to the King turned the side and accepted the Communists, and remained in their posts. On the other side, those who were firmly against the Communists during the war, were replaced in late 1944. Most prominent was the ambassadors in USA, Great Britain, with the De Gaulle's Committee and some stationed in the European neutral states. After the creation of the Tito's government in March 1945, this process reached its peak, with the introducing of several prominent Party members in several diplomatic posts, such as in the USA, USSSR, Great Britain, France and Turkey.

${ }^{69}$ J. Smodlaka, Partizanski dnevnik, Beograd 1972, 255, 260, 261.

${ }^{70}$ Arhiv Slovenije, fond 1277, Edvard Kardelj, k. 28, Podaci o činovnicima Ministarstva inostranih poslova koje je namjestio bivši ministar Šubašić. 